\title{
An African contribution to the constitutional right to modern schooling 150 years ago
}

\section{Christel Adick ${ }^{1}[\mathbb{B}$}

Published online: 19 October 2020

(C) The Author(s) 2020

\begin{abstract}
This article highlights the stipulation of the provision of formal schooling in a regional constitution drafted in West Africa in 1871, almost 150 years ago. The constitution under discussion originated in Fanteland, a coastal region of the Gold Coast (modern-day southern Ghana), and was the main achievement of a historical movement which sought to unite several smaller kingdoms and communities into a Fante Confederation (1868-1873). While the whole idea of a written constitution which includes the aspect of formal schooling may seem rather "European" or "Western" at a first glance, it is remarkable in that one would not expect it to have occurred in West Africa at that time. The author of this article argues that the Fante Constitution in fact represents a unique early African attempt to construct a modern nation-state based on a written constitution, and that the sections which stipulate and regulate formal schooling are central to its vision. The author embeds the sections concerning education in an analysis of the specific historical situation of the Fante people in West Africa before the establishment of formal British colonial rule on the Gold Coast. She develops two main theses: the constitution (a) is an "African" contribution to educational policymaking, which (b) accords "modern" schooling a crucial role in state-building. She presents these theses in the light of the historical record and competing interpretations in historical discourse.
\end{abstract}

Keywords West Africa · Fanteland · 19 th century $\cdot$ African agency $\cdot$ modern education $\cdot$ constitutional rights $\cdot$ compulsory education

\section{Résumé}

Une contribution de l'Afrique vieille de 150 ans au droit constitutionnel à une scolarité moderne - Cet article met en relief la disposition concernant l'offre de scolarité formelle prévue par une constitution régionale ébauchée en 1871, voici près d'un siècle et demi, en Afrique de l'Ouest. Cette constitution, née au Pays fanti, région

Christel Adick

christel.adick@rub.de; christel.adick@web.de

1 Faculty of Philosophy and Educational Research, Institute of Educational Research, Ruhr University of Bochum, Bochum, Germany 
côtière de la Côte-de-l'Or (l'actuel Ghana méridional), fut le principal accomplissement d'un mouvement historique qui cherchait à unir plusieurs petits royaumes et communautés en une Confédération fanti (1868-1873). Bien que de prime abord la notion de constitution écrite englobant la scolarité formelle puisse paraître « européenne » ou « occidentale », elle est remarquable du fait que l'on ne s'attendrait pas à ce qu'elle soit apparue à cette époque en Afrique de l'Ouest. L'auteure de cet article affirme que la Constitution fanti représente en fait une première et unique tentative africaine de construire une nation moderne sur la base d'une constitution écrite et que les paragraphes stipulant et régissant la scolarité formelle sont des éléments primordiaux de la vision qui y est formulée. Elle aborde ces paragraphes en les analysant à travers le prisme de la situation historique particulière du peuple fanti en Afrique de l'Ouest, avant la mise en place officielle du régime colonial de Grande-Bretagne sur la Côte-de-l'Or. Elle développe deux thèses principales : la constitution (a) est une contribution « africaine » à la politique de l'éducation, qui (b) attribue à la scolarité « moderne » un rôle décisif dans la construction de l'État, des thèses qu'elle présente à la lumière de données historiques et de différentes interprétations du discours historique.

\section{School education in national constitutions}

The object of this historical analysis is the 1871 Constitution of the Fante Confederation Movement (1868-1873), particularly the sections devoted to education in that constitution. The Fante ${ }^{1}$ case is of great relevance to the history of education in Africa. It directly entails one of the central debates on schooling in Africa, which is often characterised as "education as a colonial heritage". For better or worse, socalled "Western" schooling in Africa is viewed as either a benevolent side effect of European colonialism, or as a negative foreign (non-African) legacy that needs to be overcome.

Two initial framing issues require explication:

- "Schooling" and "education" are not equivalent. Many people, places and institutions transmit knowledge, values, competencies, behaviour and wisdom - in other words, education - without involving schooling. The school is a specific type of pedagogical institution that offers a particular kind of education. Hence, "education" is the umbrella term, while "schooling" refers specifically to formal education. ${ }^{2}$ The sections of the Fante Constitution to be analysed here clearly deal with "schooling" and not with "education" in the broader sense.

\footnotetext{
1 Throughout the literature, the spelling varies between Fante and Fanti or sometimes Fantee. In this article I use Fante and the related Asante (instead of Ashanti), following Rebecca Shumway (2015) in her comprehensive summary of the historiography of Fanteland, in which the Fante Constitution and the role of education are included but not treated in detail.

${ }^{2}$ For a discussion of the distinction between formal and non-formal education see the early clarification in the UNESCO brochure written by David Evans (1981).
} 
- The analysis should reach beyond the narrative of "Africa and Europe in the Colonial Era" to encompass a more global view of the history of schooling, both before and after colonial rule. A broad historical and international comparative approach is in order, in the tradition of Fernand Braudel and the French "Annales School" 3 of historical research considering developments of "longue durée". An awareness of the historical and geographical entanglements of the Fante case is crucial in order to understand both the origins and the implications of the schooling sections in the Fante Constitution.

The conceptualisation of education in Africa as a "colonial heritage" is ubiquitous in academic discourse, but inadequate and misleading in several ways (see Adick 1989a). It ignores African initiatives to construct modern schools; it does not differentiate between missionary and colonial education, which often did not go hand in hand; it devalues African demands for "Western-style" education as simple-minded mimicry; and - last but not least - it does not explain why generations of African parents have sent their children to such "Western" schools, or why virtually all African governments have supported and greatly expanded the inherited school systems. Instead of viewing schools in Africa as a mere colonial legacy, it would be more accurate to situate the development of schooling in Africa in the context of a global history of modern schooling.

Comparative education should re-evaluate the spread of modern schooling in the light of theoretical analyses of the modern world system. Such a comprehensive approach challenges and re-interprets frequently discussed factors such as the adoption of "European-style" educational institutions outside the Western world; the abandonment of "pre-modern" forms of schooling (not only in Africa); missionary education; the transnational expansion of modern schooling; and the universalisation of the essentials of nation-state school systems (Adick 1992, pp. 246-252). A broad and systematic approach sees the origins of schools in Africa and their development over decades and centuries as part of a global history of schooling which changed education patterns all around the world.

Political philosopher Olúfémi Táiwò offers useful thoughts on the conceptualisation of colonialism and modernity. He decries the short-sighted conflation of labels such as "colonial", "modern", "Western" and even "Christian" in opposition to "African". Táiwò posits that

modernity predated colonialism in Africa; missionaries midwifed the introduction of modernity to Africa; and modernity was driven by native agency and took place in West Africa and (for the most part) in the Anglophone areas of the region (Táiwò 2010, p. 8).

\footnotetext{
3 The Annales d'histoire économique et sociale [Annals of economic and social history] is a scholarly journal which has prompted the name of the French "Annales School". This is a group of historians whose particular interest is long-term social history. Fernand Braudel (1902-1985) was one of the leaders of this group.
} 
He goes on to say:

A sizable number of Africans was present who had been inducted into and accepted modernity and its discourses and had become proselytizers to their own people. These individuals wanted to remake their societies along modern lines before the imposition of formal colonialism (ibid., p. 9).

Táiwò (ibid., chapter 6) highlights the "Fante case" as one of the first two moderntype African constitutions, the other being the Egba United Board of Management/ Egba United Government in Abeokuta (now Nigeria) in the latter third of the 19th century. The Egba case has been considered an example of "aborted modernization in West Africa" in research by Agneta Pallinder-Law (1974). These views suggest a reconceptualisation of modernity in Africa in which the terms "African" and "modern" need not be mutually exclusive. In his 2012 manifesto, Táiwò (2014 [2012]) sustains his proactive plea for Africa to become aware of her modern past as an inspiration for tackling her future. These two approaches - placing schooling in Africa into a broader worldview and recognising the modernity of much early African thought and agency - will guide the following analysis of the Fante case and the education-related sections of the Fante Constitution.

A key feature of the modern nation-state is the formal definition of policies regarding the objectives of that state, its ruling bodies, and the role of its citizens and institutions. This view is one of the core arguments of "world polity" or "world culture" theory, an approach within international comparative education research largely attributed to John W. Meyer (Stanford University) and his co-authors, and other researchers. ${ }^{4}$

According to Meyer (1980), the emergence of a "world polity" since about the 19th century can be characterised as "a world-wide system of structurally similar nation-states" whereby the modern state represents "the most highly legitimated form of corporate social authority" (ibid, p. 117; see also Boli-Bennett 1980). As well as developing a particular stance on economic, cultural and political issues, modern nation-states also formulate and formalise a particular kind of education system. This view is supported by a content analysis of official state declarations on the essence and objectives of "their" education system (Fiala and Lanford 1987). Covering more than one hundred countries over a ten-year period (1955-1965), the authors found a repeated insistence on the relationship between education and "development", both personal and national. "Development" was accorded greater importance than other factors such as religion, local culture or political ideology. The promise of development and progress is thus assumed to be the ideological basis of the modern world. This "development ideology" also played an important role in the world educational revolution after the Second World War (Meyer et al. 1977).

Among other research within the "world culture" or "world polity" paradigm, special mention needs to be made of a comprehensive historical analysis of written

\footnotetext{
${ }^{4}$ For an overview of topics and authors of this "world culture" school of thought, see the collection of articles edited by Georg Krücken and Gili Drori (2009).
} 
constitutions going back as far as the 1870s (Boli-Bennett 1979) which I will discuss below. Meyer et al. (1997) suggest that goals regarding collective and individual progress are diffused internationally via imitation and the influence of international organisations. Many constitutions and state policies therefore resemble each other (the authors write of "standard scripts" and "isomorphism"), even though the reality on the ground may be very different in different countries, sometimes to the extent that proclaimed policies may no longer be relevant in a particular country. This disjunct between theory and practice is known as "de-coupling". Of course, in every country in the world there is a gap between practical, lived reality and what is stated in political documents such as constitutions. This does not, however, imply that such documents are meaningless.

According to this broader picture, schooling is part and parcel of any modern nation-state. The right and duty of the state to provide and regulate education, and the rights and duties of its citizens to access that education, must be politically enshrined. This global view will guide the following historical reconstruction of a specific case in the history of modern schooling in a coastal region of West Africa in the 19th century. The case looks "Western", but was in fact, I will argue, an early African attempt to construct a modern nation-state with a written constitution which stipulates how schooling is to be provided and regulated.

\section{Background to the Fante Constitution}

The following analysis centres on the education-related sections of a written constitution which originated in a specific place (the Cape Coast region on what was then the Gold Coast) and time (1868-1873). Whereas nowadays it is quite normal to find sections pertaining to education in national constitutions all around the world, this was not the case one and a half centuries ago, not even in the Western world. This does not mean that people who lacked a written constitution lived without moral guidelines and normative rules. Here, however, we are concerned specifically with written constitutions, i.e. a highly codified text format.

According to its preamble, the Fante Constitution was adopted in November 1871 by "the undersigned kings and chiefs of the Fanti [... who], after having duly discussed and considered the subject at Mankessim on the 16th day of October last and following days, have unanimously resolved and agreed upon the articles hereinafter named". 5 The document marks the apogee of several years of consultation among the kings and local rulers who were accompanied and advised by a number of "educated natives", most of whom were well-informed about international developments and contemporary views on law, politics and the like, thanks to their education and

\footnotetext{
5 If not otherwise specified, the following summary of historical events around the Fante Confederation is based on the publications of Agbodeka (1964, 1971, pp. 15-33); Kimble (1963, pp. 222-263); and Limberg (1970). The text of the constitution can be found in Casely-Hayford (1970 [1903]) and in Sarbah (1968 [1906]).
} 
contacts in England, along the West African coast, or, in some cases, in the Americas and elsewhere.

Space does not permit me to present biographical details on all the people who were involved in the "Fante case". I will, however, discuss one person who was possibly the most influential of the "educated natives" acting behind the scenes of the Fante Constitutional assembly. His story may illustrate their role. ${ }^{6}$

James Horton was born in 1835 in Freetown (Sierra Leone) to ex-slaves of Igbo origin. He was sent to mission schools and attended the local Fourah Bay Institution of the Christian Mission Society (CMS), which afforded him and two other students the opportunity to study medicine in Great Britain. The three young men received a scholarship from the English military administration, who wanted to train Africans as doctors in order to address the high mortality rate of Europeans in West Africa. Horton studied for five years at King's College, London and one year at Edinburgh, where he gained his degree in medicine (MD) in 1859. Back in Africa, he served as a surgeon in the British Army Medical Service and also as a civil commandant at various English stations in West Africa, including the Gold Coast. In 1880 he retired from British service and died in Freetown in 1883 at the early age of 48 . Besides his professional career in medicine and civil service, Horton published books and papers on a wide range of political, medical and cultural topics. He also took up the challenge of scientifically deconstructing the increasingly popular racist "theories" of his time. Arno Sonderegger (2009, pp. 207-211) discusses Horton's reaction to the racist papers of James Hunt, found in the first part of Horton's book, West African Countries and Peoples (Horton 1975 [1868]), under the heading “The Negro's Place in Nature", which directly refers to James Hunt's pamphlet of the same title published in 1863 (Hunt 1863).

Horton was a key figure in spearheading the development and modernisation of education in Africa. Over and over again he demanded higher education for Africans in Africa, public education, general secondary education (grammar schools, public schools), government-sponsored teacher training, a medical college for West Africa, and most emphatically, a University for West Africa, which he first suggested in 1862 (Adick 1989b, pp. 52-54). For him, modern education - meaning the establishment of schools of all levels up to college and university - would contribute to development and progress in Africa, assuming that the institutions should come under African control.

Critics will argue that the very ideas of formal schooling or constitutions were imported from the West and thus cannot be called "African". Against this I would argue that the adoption of ideas or innovations from elsewhere should not be dismissed as mere mimicry, provided that the innovations are self-directed by and for local societies. After all, learning from the experiences of others is an essential part of education and development, regardless of where one is situated.

\footnotetext{
${ }^{6}$ See Adick (1989b, pp. 51-54), where Horton's contribution to education in Africa is presented as "modernisation" in contrast to another important African philosopher, Edward Wilmot Blyden (18321912), whose position is characterised as favouring "Africanisation".
} 
Horton has also been criticised for his allegedly European thinking by African intellectuals like Emmanuel Ayankanmi Ayandele, who wrote that he was "undoubtedly the most thoroughly culturally conquered of the leading African educationists of the nineteenth century in West Africa" (Ayandele 1972, p. 121). However, Horton is being rehabilitated by more recent researchers (e.g. Boele van Hensbroek 2004, pp. 83-86), and particularly by Táiwò (2010, pp. 115-122), who rates Horton as one of the leading "African Apostles of Modernity" in the 19th century. Whatever interpretation prevails, this short glimpse of the African intellectual James Horton should suffice to illustrate the crucial role played by "educated natives" as consultants, brokers and innovators in the Fante case.

\section{The education-related sections of the Fante Constitution}

The Fante Constitution regulated jurisdiction, political representation, public budget and administration; in short, it codified general principles pertaining to political, economic and social affairs. Táiwò (2010, pp. 209-218) notes the modernity of the legal concepts in the constitution, which refer to principles such as "governance by consent", "separation of powers", "blending the Old and the New" and "leading in the name of progress". The last point echoes what has already been said about the focus on development and progress in modern policymaking around the world.

Having set this general political and philosophical background, I will now turn my attention to the specific role of education in this remarkably modern constitution.

Box 1 presents the sections of the Fante Constitution of 1871 concerning education. The emphasis placed on education in the constitution demonstrates the importance of schooling for the nascent state. However, the different types and names of schools (e.g. national schools, Wesleyan schools, etc.) lack further definition. Their meaning will become clearer in the following analysis.

The Fante Constitution recommends the establishment of a public school system for all Fante children aged between 8 and 14. The political importance of this system in terms of the overall modernisation envisaged in the constitution is illustrated in $\S 8$, in which education is placed on the same level as other important state affairs such as defence, development, infrastructure, agriculture, industry and resources. Of all these, only schooling and roads receive specific and more detailed treatment later (sections 20-26), and schooling receives by far the most extensive attention.

The constitution recommends that schools be erected for all the children of the confederation, and that these schools be staffed with competent teachers $(\S 8$, item IV.). As soon as possible, national schools should be operating in every district ( $\$ 21)$, supported by normal schools ${ }^{7}$ for vocational training ( $\left.\$ 22\right)$. Furthermore, the constitution caters for girls' education, including trained female teachers $(\S 23)$.

\footnotetext{
7 The term "normal school" usually refers to an establishment dedicated to teacher training. In this case, however, it denotes a school for practical skills such as crafts and vocational training (according to Foster 1971, p. 101).
} 
Box 1 The sections of the Fante Constitution of 1871 concerning education

§ 8. That it be the object of the Confederation:

I. To promote friendly intercourse between all the kings and Chiefs of Fanti, and to unite them for offensive and defensive purposes against their common enemy.

II. To direct the labours of the Confederation towards the improvement of the country at large.

III. To make good and substantial roads throughout all the interior districts included in the Confederation.

IV. To erect school-houses and establish schools for the education of all children within the Confederation, and to obtain the Service of efficient school-masters.

V. To promote agricultural and industrial pursuits, and to endeavour to introduce such new plants as may hereafter become sources of profitable commerce to the country.

VI. To develop and facilitate the working of the mineral and other resources of the country.

\$ 21. That national schools be established at as early a period as possible in the following districts: Braffoo country, Abrah, Ayan, Gomowa, Ekunfi, Edgimacoe, Denhia and Assin.

\$22. That normal schools be attached to each national school for the express purpose of educating and instructing the scholars as carpenters, masons, sawyers, joiners, agriculturalists, smiths, architects, builders, etc.

§ 23. That schools be also established, and schoolmistresses procured to teach the female sex, and to instruct them in the necessary requisites.

\$24. That the expense for erecting each school be defrayed from the national purse, but that each king and chief be requested to render all possible aid to facilitate the movement by supplying men and materials.

§ 25. That in districts where there are Wesleyan schools at present established, the kings and chiefs be requested to insist on the daily attendance of all children between the ages of eight and fourteen.

$\S 36$. That it be the duty of the provincial assessors $-(\ldots)$

para 6: To see that the national schools are attended by all children between the ages of eight and fourteen, and to report thereon to the secretary.

Source Text of the Fante Constitution of 1871 according to J.E. Casely-Hayford (1970 [1903], pp. 327340); or John Mensah Sarbah (1968 [1903], pp. 199-209)

It stipulates that education should be financed by public budgets including local contributions ( $\$ 24)$.

It is clear that the authors of the constitution were aware of the prevailing realities in their confederation, where schools (run by missionary societies) already existed in some areas but not in others. The coastal areas which fell under the Fante Confederation had long witnessed the spread of Wesleyan Methodist schools, ${ }^{8}$ whereas inland schools were still rare. This social context prompted the authors of the constitution to specify who would have administrative authority over the schools as follows: In districts where (Wesleyan) schools already existed, the schools should fall under the control of local kings or chiefs who were responsible for ensuring regular school attendance of all children aged 8 to 14 (§ 25). In the "national schools" which had yet to be erected in the inland districts specified in $\S 21$, authority would be in the hands of provincial assessors (\$ 36, para. 6). "National school" therefore

\footnotetext{
${ }^{8}$ Wesleyan Methodism is a Protestant Christian denomination. The establishment of Wesleyan Methodist Missionary Society schools in West Africa is discussed later in this article.
} 
clearly meant "non-missionary" (i.e. non-Wesleyan) school. Here again, the provincial assessors are charged with overseeing both road construction and school attendance, again demonstrating the importance accorded to schooling in this constitution. $\S 34$ states that the undersecretary is to report on both of these principal targets (the development of roads and schools) based on reports from the provinces. This shows that the authors had given consideration to mechanisms for monitoring progress.

In sum, these sections document a very progressive and comprehensive vision of compulsory education for boys and girls aged 8 to 14, taught by trained teachers and including vocational training in agriculture, industry, commerce, and the extraction of the country's mineral and other resources ( $\$ 8$, items V and VI).

We are now in a position to consider the extent to which the Fante Constitution is "African" and "modern". One might think the constitution was a copy of an English model, since it was drafted in part by "educated natives" who had lived and studied in England. This cannot be the case, however, for the simple reason that England does not and did not have a written constitution to copy. ${ }^{9}$ Perhaps British administrators might have drafted the Fante Constitution from behind the scenes? Again, there is no mention in the literature of any foreign (i.e. non-African) consultant who might have participated in the formulation of the document. All evidence points to the idea that the writers of the Fante Constitution spoke by and for themselves. If anything, it would be the "educated natives" who would then have to be regarded as foreigners. This leads to the question of how "foreign" (and consequently alienated) an African actor should be classified as just because he or she suggests an idea or acts along lines that have non-African origins. In a global world, it is quite normal to learn from the experiences of other people or countries. Why should it be a sign of subordination to acquire knowledge and competences from elsewhere? It is high time we regarded the Western-educated Fante as being every bit as "African" as their compatriots who did not (yet) have experiences with European-type schools, or those who rejected them.

The answer to the question "Can the Fante Constitution and its education-related sections be classified as 'modern'?" is therefore a resounding yes. Comparative research on historical constitutions by John Boli-Bennett (1979) supports this view. Although not specifically concerned with rights and duties in education, Boli-Bennett's content analysis of all available constitutions in the year 1870 (39 constitutions from 47 countries) shows that the right to education and the duty of the state to provide it scored an index value of 0.21 (on a scale from 0 to 2 ). In other words, it was very low (Boli-Bennett 1979, p. 227). The research covered a hundred years in 20-year intervals up until 1970. Even 20 years after the Fante Constitution, in the sample taken from the year 1890, the education index had only climbed to 0.55 , which was still very low compared to later times. This indicates that a state-controlled compulsory education system stipulated in a national constitution was still a rarity at the time of the Fante Constitution, even in Western countries. According

\footnotetext{
9 This, of course, does not mean that England had no written rules and regulations. Further research would be required to identify possible similarities between the Fante Constitution and contemporary English legal documents.
} 
to other comparative research, the notion of compulsory education only took hold in a few European countries from the 18th century onwards; in most countries it was not introduced until much later and implemented in practice later still (see Mangan 1994). The fact that the Fante Constitution "looks" so "Western" therefore does not diminish its value as an African accomplishment, because copying or imitating constitutions is a normality in the modern world.

The ideology of state authority is, then, a world-system phenomenon in which constitutions represent, beyond their descriptive and prescriptive properties, responses by the national elites to world political ideology: These responses are highly uniform because every national elite faces roughly the same world ideology and has roughly the same goals in the nation-state status competition (Boli-Bennett 1979, p. 235).

Countries are inspired by other countries, and constitution texts accordingly follow a predictable pattern. The sections of the Fante Constitution would appear quite progressive in such a "copy-and-paste" comparison if measured by concepts like the one offered by Táiwò (2010), who defines modernity as follows:

What is distinctive about modernity is not so much that it builds high technology and creature comforts but that it enjoins modes of being human that have been considered superior to previous and alternative forms in human history. That is, the distinctive marker of modernity is to be found in its politico-philosophical discourses that can be summed up in three key concepts: subjectivity, reason, and progress (ibid, p. 5, italics in the original).

Similar arguments are reiterated in other chapters of his book (e.g. Táiwò 2010, pp. 101-103). The Fante Constitution may be classified as "modern" because it addresses the individual person as the learning subject. Every child should attend school and gain knowledge and skills by him- or herself. The intention of "bookish learning" of the sort provided in a formal institution such as a school is to increase the learner's reasoning capacity. Moreover, the envisaged national Fante education system is presented as a vehicle for societal progress. All of these factors underscore the modernity of the Fante Constitution.

\section{Looking for explanations: how the Fante Constitution came about and why it ultimately failed}

The Fante Constitution of 1871 was the codified vision of a new political alliance known as the Fante Confederation (1868-1873). There had been previous alliances between Fante communities and kingdoms in times of crisis (see McCarthy 1983). These, however, had not been formalised by a written constitution. The choice of Mankessim as the venue signals a historical attachment to the traditional ritual centre of the Fante, who wanted to demonstrate a sense of unity and continuity even though a written constitution was something new, the idea of which had almost 
certainly been introduced by "educated natives", as noted above. The participants agreed on a mix of "traditional" and "modern" principles:

The educated leaders could not attract the mass of the peoples over the chiefs' heads; and the kings and chiefs needed the educated men to handle their correspondence and to advise and help them, but the influence of the educated men gradually grew stronger (Limberg 1970, p. 84).

The assembly discussed and sought to formulate Fante policies towards the peoples of adjacent kingdoms like the Asante and the Elminas, but also towards European powers like the Dutch, Danish and British, whose overseas trade companies occupied a range of fortified coastal stations also bordering on Fanteland, e.g. Cape Coast Castle. These "trade castles" reflected the long history of the transatlantic slave trade as part of the so-called triangular trade connecting Western Europe, West Africa and the Americas. ${ }^{10}$ After the British formally abolished the Atlantic slave trade in 1807 , other countries followed suit, even though it took decades for the slave trade on the shores of West Africa to decline while new economic and political constellations developed between Europe and Africa. This new historical situation ushered in an era of social change which, importantly, left room for manoeuvre. Europeans were few, as it was not yet clear what kinds of commodities would replace the slave trade after its abolition. The European traders and administrators of the castles were not all-powerful and were even undecided about their own future policies, as is shown by two documents:

- A Resolution of the Select Committee of the British House of Commons recommended in 1865 that "the object of the policy of the Government should be to encourage in the natives the exercise of those qualities which may render it possible for it more and more to transfer to them the administration of all the governments, with a view to our ultimate withdrawal from all, except, perhaps, Sierra Leone" (ref. in Horton 1978 [1868], p. 69). This looked like an imminent British withdrawal instead of an incitement for colonial adventures on the Gold Coast and other parts of West Africa, and as such could have been understood as an encouragement to constitute a new political order under local African selfcontrol.

- Another official British document among the 1867 papers of the British House of Commons confirmed limited territorial control by stating that "according to custom and usage, the territory belonging exclusively to Great Britain, on the Gold Coast, extends to the distance of a cannon shot (or five miles) from each of the undermentioned castles and forts" (Crooks 1973 [1923], p. 371). A few patches of land around trade stations hardly constituted a "colonial territory". Hence, the Africans who lived near the forts and further inland controlled their daily lives and fates according to their own laws and customs. European interests and interference were weak; colonial dominance was yet to come.

\footnotetext{
10 According to the map in Lawrence (1963, pp. 14-15) there were about 30 such fortified stations on the Gold Coast which were operated by different European actors at different times.
} 
In December 1867, representatives of the Fante coastal states and communities assembled to draw up a constitution. Why? What had happened? In 1867, the British and the Dutch had agreed to exchange some of their forts on the Gold Coast, without consulting the local kings and chiefs. Why did the Fante object to this? It was common practice that the fort areas were leased to the European companies according to the "landlord-stranger-principle": the European trade companies had to pay rent and duties to the African rulers, but the territory was neither sold to them, nor were the Fante people under their political control. The forts symbolised a semi-permanent European-African trade alliance. Additionally, some local rulers had signed a "Bond" in 1844 which placed the jurisdiction of capital offences in the areas around the trade stations into the hands of the English governors of the respective trade castles. But since ordinary jurisdiction and control rested with the African population, this "bond" should not be misunderstood as indicating that these African chiefs and kings had agreed to be subjects of an alien, colonial rule. The pacts and common practices between Fante and English representatives were not understood in terms of political subordination. Rather, they served the interests of a coastal people in becoming familiar with some modern European customs and technologies, while at the same time sustaining their position on the coast in relation to the expansive Asante kingdom of the hinterland, with whom they had already fought several wars (see Agbodeka 1964).

At this point, the special role of the "educated natives" comes back into focus. One might think that these Western-educated Africans in the 19th century were the products of missionary or colonial schools installed for them by European agencies operating in West Africa. This view, however, betrays a misunderstanding of the social realities of pre-colonial times. Missionary stations were rare and, moreover, were often run by Africans, since many Europeans fell ill or died on this coast known as the "white man's grave". (Once treatment for malaria had been discovered, more Europeans came and lived longer on these coasts, a fact which might even have enhanced colonialism.) Schools did exist on the premises of some of the trade stations like Cape Coast Castle, but in a haphazard way, arbitrarily staffed with little continuity and influence outside the castle area.

This changed dramatically from the 1830s onwards after the abolition of the Atlantic slave trade, when ex-scholars of the Cape Coast Castle school founded the "Cape Coast Society for the Promotion of Christian Knowledge" (also known as the "Bible Band") in 1831. This initiative, which was African, should be considered the origin of the Methodist church on the Gold Coast, since it led to the arrival of the first English missionary of Wesleyan Methodist denomination (see Southon 1934). Wishing to enhance their studies, and because they felt they did not have enough books, the "Bible Band" had asked the captain of an English ship to provide them with teaching materials upon his return to the Gold Coast. Back in England this captain contacted his acquaintances among the Wesleyan Methodists. The request for instruction kits was then taken up by the Mission Society as a chance to start mission work on the Gold Coast. This was begun in 1835 by sending the first English Methodist Missionary, Joseph Rhodes Dunwell, to minister to the school leavers of Cape Coast Castle. Even though Dunwell died six months after his arrival, as did many other missionaries from England who followed in the ensuing decades, the 
self-initiated school work continued under African teachers. The numbers of schools and pupils in the Cape Coast area increased considerably, reaching 45 schools with 1,986 students in 1860. Methodist school and mission work in the Fante area was, then, largely the work of African protagonists who were representing - as the chronicler Arthur E. Southon underscores - "in essence, an indigenous Church" (Southon 1934, p. 114).

From all this it follows that a good number of Africans who worked as missionaries, teachers, traders or clergy were familiar with "Western" education, some of them (like Horton) even by way of having studied in England. These "educated natives" highlight the social change that was taking place in the 19th century - before colonialism. Some came from the local populations and had gone to school in Cape Coast Castle or had even been to Europe. Some were the children of an African mother and a European father; these people enjoyed no special status, since they were considered as Fante according to the descent rules of the local communities. ${ }^{11}$ Other "educated natives" came from groups of ex-slaves who had returned to designated settlements meant for them in Sierra Leone and Liberia, from where they ventured to other areas along the West African coast. Still others belonged to the so-called "re-captives" who had never arrived in America, because they were captured (again) in order to be freed by British ships patrolling the coast for slave ships which were about to cross the Atlantic Ocean. Unlike in other parts of West Africa, the latter two groups (returnees and re-captives) were fewer in number among the "educated natives" in Fanteland than those coming from local Fante families.

Another often underrated sign of social change concerns the economic and technical developments of the time, which had diffused from the coast to regions of the hinterland. In the 1830s, simple and cheap techniques for converting palm oil into soap, candles or lubricants were discovered in England, which increased the production and trading of palm oil both among the Fante on the Gold Coast and in other parts of West Africa. The volume of palm oil exported from the Gold Coast tripled between 1830 and 1840 and involved increasingly rural populations (Sanders 1982, p. 60) in meeting the rise in demand. This in turn increased the circulation of cash and paid labour both along the coast and inland, a fact which is reflected in the issuing of administrative rules for recruitment and payment of local labourers by the British (Kimble 1963, p. 10). According to research findings, cheap industrial products were marketed up to 100 miles inland via local retail routes (Reynolds 1985, p. 203). In 1868, about 60 per cent of the overseas trade of West Africa was with the then leading industrial power, Great Britain, and 20 per cent with France (ibid, p. 204).

These economic developments led to a demand for skilled labour, because they entailed intensified communication between Western Europe and West Africa due to the introduction of regular steamship services. These ships transported not only commodities but also information and ideas, disseminated, for example, in books and newspapers like the African Times, which originated in London in 1861. This

\footnotetext{
11 Fante society was matrilineal: that is, children were regarded as Fante when they were born to a Fante mother (see Lever 1970).
} 
newspaper was printed just in time before the ships headed from London to West Africa to reach around 350 subscribers and, through them, most probably a far larger number of non-subscribed readers (Kimble 1963, p. 192). The existence of a regular steamship connection was also undoubtedly valuable for a considerable number of Africans who went to England for commercial purposes or to study at colleges and universities, as many biographies of Africans in Europe (e.g. those collected by Debrunner 1979) illustrate. Regular exchange flourished between the British-influenced regions of West Africa, involving a diverse group of "transnationally mobile" West African missionaries, traders, teachers, interpreters, journalists, skilled craftsmen and intellectuals who circulated between places like Freetown, Cape Coast, Accra, Abeokuta and Lagos, exchanging ideas and capital as they went.

These developments illuminate how and why the move to a confederation-based constitution came about. It was a self-empowered reaction to the unannounced exchange, in 1867, of forts among the European companies over the heads of the Fante authorities. This aroused concern among and protest from the "traditional" as well as the "modern" strata of Fante society. The traditional rulers objected because they were the sovereigns of the land, and the "educated natives" felt it was a hypocritical move by a British establishment which recommended "native agency" and encouraged Africans to conceptualise a new political regime for their own society. The historical situation in the aftermath of the Atlantic slave trade was caught between the seemingly laissez-faire policy of the English colonial offices in London, the Asante kingdom striving to extend its control southwards, and the Fante working to sustain or contest their political interests and economic position in coastal and overseas trade.

The federation and constitution were not meant as a declaration of war against the British presence on the Gold Coast. They did, however, signal that the Fante had united under the vision of a new polity which wanted to cooperate with others, including the British, on an equal footing.

From today's perspective, the next step they took might appear naïve: members of the Fante Executive Council presented their constitution to the chief British representative on the Gold Coast, C. S. Salmon - upon which they were arrested for conspiracy (see Salmon's letter, reprinted in Metcalfe 1964, p. 338). However, London heavily criticised Salmon's verdict, and those who had been arrested had to be released again. Although there were quibbles over whether certain points in the constitution would accord with British-style diplomacy, the "Fante case" was essentially welcomed by the British authorities.

Her Majesty's Government have no wish to discourage any legitimate efforts on the part of the Fantee kings and chiefs to establish for themselves an improved form of government, which, indeed, it is much to desire that they should succeed in doing; but so long as they live under the protection of Great Britain, the Protecting Government must be consulted as to any new institutions which may be proposed (the Earl of Kimberley to Sir Arthur Kennedy, London, 16 January 1872, reprinted in Metcalfe 1964, p. 339).

The British referred to their role as one of "protection", not colonial rule. The Fante, for their part, wanted self-control - a difference which might have caused conflict in 
the future if the confederation had succeeded in constructing a viable independent and lasting state on the coast. But instead of speculating about what might have been, it is more important to expose the gap between official British policy made in London and the local policies of the British representatives on the Gold Coast. Whereas official policy had no issue with the self-articulation of "natives" in West Africa, the local British representatives were suspicious, and ultimately paved the way for the upheaval that followed. Their targets were the "educated natives" whose ascent, in their view, had to be stopped - even if this meant siding with the "traditional rulers". W. H. Simpson, the predecessor of the above-mentioned "acting administrator" C. S. Salmon, led this campaign against the educated members of the Fante. Having been invited to visit the Fante meeting at Mankessim in 1868, Simpson described how he anticipated the "pernicious interference of the 'scholars' or semi-educated natives hitherto in uncontrolled ascendency" (ref. in Metcalfe 1964 p. 325f.). And in 1872, C.S. Salmon continued to discredit them as selfish people who would overrun the unsuspecting kings and chiefs to further their own ends:

The worst feature in the new constitution is the complete manner in which all power is taken from the native kings and placed in the hands of the "Ministry" and "Executive Council", composed of young men, some of doubtful respectability, and none with any means, or holding any position in the country (ref. ibid, p. 340).

The years following the arrest and re-release of the Fante representatives saw some new attempts to establish the confederation in a format which would serve Fante and British interests alike, but these ultimately failed. The English representatives multiplied existing suspicions and incited dissent between the traditional rulers and the "educated natives", until finally it was the Fante rulers who allegedly sought "British protection", perhaps not least because another military conflict with the Asante kingdom was imminent. In 1874 the British erected a "Crown Colony" in the Fante confederation territories plus some adjacent regions to the East, but not (yet) including either the Asante kingdom or the Northern Territories (which only much later formed the Gold Coast Colony). Now the Colonial Office in London declared that the educated natives "have been, are, and are likely to be the source of much trouble to the administration of affairs upon the West African coast", to which Simpson's personal recommendation was added, reading: "I would have nothing to do with the 'educated natives' as a body, I would treat with the hereditary Chiefs alone, and endeavour as far as possible to govern through them" (ref. in Kimble 1963, p. 259f.).

The creation of a crown colony over some southern areas of the Gold Coast in 1874, which was later enlarged to become the Gold Coast Colony, was in any case the turning point towards the establishment of colonial rule. It is debatable whether this came about more in response to requests for protection from local Fante rulers or under pressure from local British representatives. As we have seen, it already incorporated the principles of "indirect rule" for which the British Empire became famous. At the same time this spelled the end of the modern, and yet African, Fante Confederation and Constitution of those days - 150 years ago.

In conclusion, the Fante Confederation and its Constitution did not bring about a viable new state including a national school system. However, their historical 
"experiment" merits special recognition, because it reveals a vibrant initiative on the part of Africans to speak for and by themselves before colonial rule was established. It is also notable for its emphasis on social and economic development via modern education for all children - an emphasis that was far ahead of its time. Whereas countries nowadays generally have a written constitution or other functional equivalents that define the duties of the state to provide education and the right of the citizens to participate in it, this was not yet taken for granted in the 19th century. Seen from this perspective, the Fante concept of education was very progressive, not least by calling for publicly controlled compulsory schooling for girls as well as boys, and for professional teachers who were not yet common around the world, even in Europe.

Instead of devaluing this self-directed African initiative as a "colonial heritage" or a mere imitation of a "Western" model, the education-related sections of the Fante Constitution of 1871 should be seen as a specific variety of a universal model of modern schooling (Adick 1992) which is characterised (over and above cultural peculiarities) by structural features common to all national, state-controlled education systems. These include, but are not limited to: compulsory education; a differentiated school system (school classes and levels and types of schools); public finances and regulations; professional teaching personnel; and development orientation. This fundamental concept of schooling as a universal right which the state is required to provide still prevails today. It formed the blueprint for the UNESCO-monitored Education for All agenda (1990-2015) and is reflected in the United Nations Sustainable Development Goals (SDGs), to be achieved by 2030. One of these 17 goals, SDG 4, is devoted solely to education. The first of its ten targets aims to "ensure that all girls and boys complete free, equitable and quality primary and secondary education" (UNESCO 2016, p. 18). The Fante Constitution 150 years ago wanted schools for all girls and boys aged 8 to 14 . Although not quite equivalent to SDG 4, this was surely a very modern idea for its time.

Funding Open Access funding enabled and organized by Projekt DEAL.

Open Access This article is licensed under a Creative Commons Attribution 4.0 International License, which permits use, sharing, adaptation, distribution and reproduction in any medium or format, as long as you give appropriate credit to the original author(s) and the source, provide a link to the Creative Commons licence, and indicate if changes were made. The images or other third party material in this article are included in the article's Creative Commons licence, unless indicated otherwise in a credit line to the material. If material is not included in the article's Creative Commons licence and your intended use is not permitted by statutory regulation or exceeds the permitted use, you will need to obtain permission directly from the copyright holder. To view a copy of this licence, visit http://creativecommons.org/licen ses/by/4.0/.

\section{References}

Adick, C. (1989a). Education in the modern world system: An attempt to end the mythology of the concept of education as a colonial heritage. Education (A biannual collection of recent German contributions to the field of educational research), 40, 30-48. 
Adick, C. (1989b). Africanization or modernization? Historical origins of modern academical education in African initiative. Liberia-Forum, 5(8), 50-62. Retrieved 10 August 2020 from https://www. pedocs.de/volltexte/2017/14814/pdf/Adick_1989_Africanization_or_modernization.pdf.

Adick, C. (1992). Modern education in "non-Western" societies in the light of the world systems approach in comparative education. International Review of Education, 38(3), 241-255. https://doi. org/10.1007/BF01101431.

Agbodeka, F. (1964). The Fanti Confederacy 1965-1869, an enquiry into the origins, nature and extent of an early West African protest movement. Transactions of the Historical Society of Ghana, 7, $82-123$.

Agbodeka, F. (1971). African politics and British policy in the Gold Coast, 1868-1900. Evanston, IL: Northwestern University Press.

Ayandele, E. A. (1972). James Africanus Beale Horton: Pioneer philosopher of Western education in West Africa. West African Journal of Education, 16(2), 115-121.

Boele van Hensbroek, P. (2004). Some nineteenth-century African political thinkers. In K. Wiredu (Ed.), Companion to African philosophy (pp. 78-89). Malden, MA: Blackwell.

Boli-Bennett, J. (1979). The ideology of expanding state authority in national constitutions 1870-1970. In J. W. Meyer \& M. T. Hannan (Eds.), National development and the world system: Educational, economic and political change 1950-1970 (pp. 222-273). Chicago: University of Chicago Press.

Boli-Bennett, J. (1980). Global integration and the universal increase of state dominance, 1910-1970. In A. Bergesen (Ed.), Studies in the modern world system (pp. 77-107). New York: Academic Press.

Casely-Hayford, J. E. (1970 [1903]). Gold Coast native institutions. London: Frank Cass.

Crooks, J. J. (1973 [1923]). Records relating to the Gold Coast settlements from 1750 to 1874. London: Frank Cass.

Debrunner, H. W. (1979). Presence and prestige: Africans in Europe before 1918. Mitteilungen der Basler Afrika Bibliographien series (Vol. 22). Basle: Basler Afrika Bibliographien.

Evans, D. R. (1981). The planning of nonformal education. Fundamentals of educational planning series, no. 30. Paris: UNESCO International Institute for Educational Planning (IIEP). Retrieved 10 August 2020 from https://unesdoc.unesco.org/ark:/48223/pf0000076764.

Fiala, R., \& Lanford, A. G. (1987). Educational ideology and the world educational revolution, 19501970. Comparative Education Review, 31(3), 315-332. https://doi.org/10.1086/446694.

Foster, P. (1971). Education and social change in Ghana. London: Routledge and Kegan Pau.

Horton, J. A. B. (1978 [1868]). West African countries and peoples, British and native. Millwood, NY: Kraus Reprint.

Hunt, J. (1863). On the negro's place in nature. London: Anthropological Society/Trübner \& Co.

Kimble, D. (1963). A political history of Ghana. The rise of Gold Coast nationalism 1850-1925. Oxford: Oxford University Press at the Clarendon Press.

Krücken, G., \& Drori, G. S. (Eds.). (2009). World society: The writings of John W. Meyer. Oxford: Oxford University Press.

Lawrence, A. W. (1963). Trade castles and forts in West Africa. London: Jonathan Cape.

Lever, J. T. (1970). Mulatto influence on the Gold Coast in the early nineteenth century. African Historical Studies, 3(2), 253-261. https://doi.org/10.2307/216216.

Limberg, L. (1970). The economy of the Fanti confederation. Transactions of the Historical Society of Ghana, 11, 83-103.

Mangan, J. A. (1994). A significant social revolution: Cross-cultural aspects of the evolution of compulsory education. London: Woburn Press.

McCarthy, M. (1983). Social change and the growth of British power in the Gold Coast: The Fante states 1807-1874. Lanham, MD: University Press of America.

Metcalfe, G. E. (1964). Great Britain and Ghana: Documents of Ghana history, 1807-1957. London: Thomas Nelson.

Meyer, J. W. (1980). The world polity and the authority of the nation-State. In A. Bergesen (Ed.), Studies in the modern world system (pp. 109-137). New York: Academic Press.

Meyer, J. W., Ramirez, F. O., Rubinson, R., \& Boli-Bennett, J. (1977). The world educational revolution. Sociology of Education, 50(4), 242-258. https://doi.org/10.2307/2112498.

Meyer, J. W., Boli, J., Thomas, G. M., \& Ramirez, F. O. (1997). World society and the nation-state. American Journal of Sociology, 103(1), 144-181. https://doi.org/10.1086/231174.

Pallinder-Law, A. (1974). Aborted modernization in West Africa? The case of Abeokuta. Journal of African History, 15(1), 65-82. https://doi.org/10.1017/S0021853700013244. 
Reynolds, L. G. (1985). Economic growth in the third world, 1850-1980. New Haven: Yale University Press.

Sanders, J. (1982). Palm oil production on the Gold Coast in the aftermath of the slave trade: A case study of the Fante. International Journal of African Historical Studies, 15(1), 49-63. https://doi. org/10.2307/218448.

Sarbah, J. M. (1968 [1906]). The Fanti national constitution: A short treatise on the constitution and government of the Fanti, Asanti, and other Akan tribes of West Africa. Cass library of African studies; Africana modern library, no. 3. London: Frank Cass.

Shumway, R. (2015). From Atlantic Creoles to African nationalists: Reflections on the historiography of nineteenth-century Fanteland. History in Africa, 42, 139-164. https://doi.org/10.1017/hia.2015.22.

Sonderegger, A. (2009). A one-sided controversy: James Hunt and Africanus Horton on The negro's place in nature. In U. Pallua, A. Knapp, \& A. Exenberger (Eds.), (Re)figuring human enslavement: Images of power, violence and resistance (pp. 193-222). Innsbruck: Innsbruck University Press.

Southon, A. E. (1934). Gold Coast Methodism 1835-1935. London: Methodist Book Depot.

Táiwò, O. (2010). How colonialism preempted modernity in Africa. Bloomington, IN: Indiana University Press.

Táiwò, O. (2014 [2012]). Africa must be modern: A manifesto. Bloomington, IN: Indiana University Press.

UNESCO (United Nations Educational, Scientific and Cultural Organization). (2016). Incheon declaration and Framework for action for the implementation of Sustainable Development Goal 4. Towards inclusive and equitable quality education and lifelong learning opportunities for all. Education 2030. Paris: UNESCO. Retrieved 17 September 2020 from https://unesdoc.unesco.org/ark:/48223/ pf0000245656.

Publisher's Note Springer Nature remains neutral with regard to jurisdictional claims in published maps and institutional affiliations.

Christel Adick held the Chair of Comparative Education at the Institute of Education Research of the Ruhr-University Bochum (Germany) from 1983 until her retirement in 2013. Her research encompasses historical-comparative research of modern schooling, in particular the history of education in Africa and the Caribbean, including colonial times. Other domains are theoretical debates on education in the modern (capitalist) world system (globalisation, convergence and divergence, transnationalism, commodification, cultural capital) and pedagogical concepts of global education, including international transfer of education and education for sustainable development. 